\title{
ON THE WANT OF A KNOWLEDGE OF THE ANIMALS OF THE GENUS OLIVA AS A MEANS TO THE DETERMINATION OF THE SPECIES.
}

\author{
By F. G. Bridgman.
}

Read 8th May, 1903.

\section{[ABSTRACT. $]$}

THE object of this paper was to urge the importance of an investigation of the animals of the genus Oliva, with a view to determining what forms might rightly be considered distinct species and what varieties only.

The absence of sculpture on their shells, all forms presenting a perfectly smooth surface, and the great variation of colour and markings in many of them, rendered it particularly difficult to determine some of the species. Even the columella plaits, which vary in number in members of the same species, and become more or less obliterated by the additional deposits of enamel during the growth of the shell, assisted very little in separating the different forms; whilst no material change in the form of the shell takes place with the growth of the animal, only a thickening of its substance by depositions of additional layers of enamel. Hence there would always be much doubt and difference of opinion as to species and varieties, until some knowledge of the animals assisted in their determination. While certain forms, such as $O$. angulata, Lamk., O. porphyria, Lamk., O. Peruviana, Lamk., etc., appeared to leave little doubt as to their being distinct species, others, through their numerous varieties, in some cases so nearly approached each other as to render it almost impossible to determine to which species many specimens belong.

The colour of the interior in some cases appeared a distinctive feature, and varied but little, as in O. ispidula, Linn., O. cruenta, Sol., O. episcopalis, Lamk., etc. This, however, was not the case in the 0 . erythrostoma, Lamk., group, many varieties of colour and shade being found, and the author was inclined to believe that O. erythrostoma, Lamk., O. tremulina, Lamk., and O. nobilis, Reeve, were but varieties of one species; for, unless the deep orange interior of O. erythrostoma were to be considered a distinctive character, he could not, after examining a great number of specimens, find any reason for separating them. He thought there was room for doubt as to O. maura, Lamk., O. tricolor, Lamk., O. elegans, Lamk., O. glandiformis, Lamk., O. leucostoma, Ducl., and O. tigrina, Lamk., being all distinct species ; and the same might be said of O. episcopalis, Lamk., O. ornata, Mar., and O. cylindrica, Mar. Irregular patches of yellow are faintly distributed on many specimens of the O. episcopalis group, 
which appeared to the author to connect them to some extent with O. cryptospira, Ford, and O. irisans, Lamk. The interiors of these, however, differ in colour.

Some species, which varied much in colour and markings, were easily distinguished by some distinctive character, as 0 . inflata, Chem., and O. ispidula, Linn.; others, however, appeared to vary very little, and were determined without difficulty, such as 0 . splendidula, Sowerby. Where well-marked distinctive characters were absent, as in the 0 . reticularis, Lamk., group, an investigation of the animals would be necessary ere the species could be settled.

Some forms less variable than others appeared to present two marked varieties : a larger and lighter, and a smaller and darker (e.g., O. episcopalis, Lamk., O. cruenta, Sol., etc.). This had been noticed by both Lovell Reeve and Marrat, as seen by the illustrations in their monographs, but was not commented upon by them. These variations might indicate different sexes, or they might be only local varieties.

There was a callus on the columella of $O$. Peruviana, Lamk., var. coniformis, which was not to be found, as far as the author had observed, in the type form, and which he thought clearly pointed to some difference in the animals.

Localities might, of course, have an important bearing upon species, but the author was unwilling to admit that a difference of locality would alone be sufficient to separate them, nor were the localities given for the different varieties of forms always to be implicitly relied upon. 


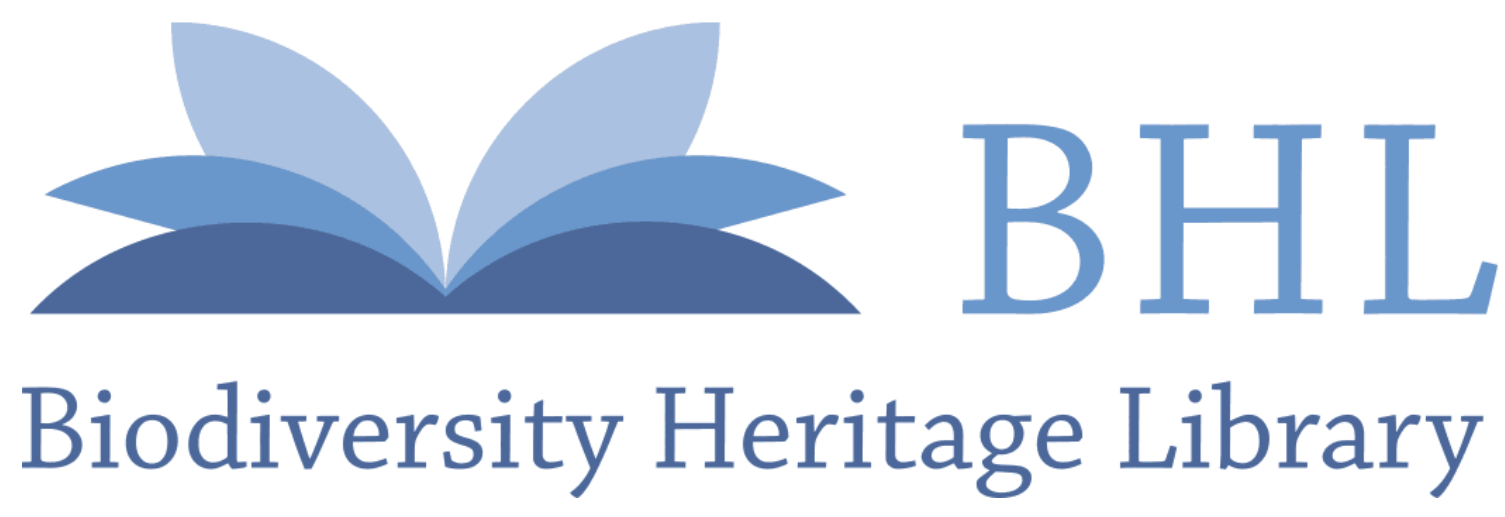

Bridgman, F. G. 1903. "ON THE WANT OF A KNOWLEDGE OF THE ANIMALS OF THE GENUS OLIVA AS A MEANS TO THE DETERMINATION OF THE SPECIES." Proceedings of the Malacological Society of London 5, 346-347.

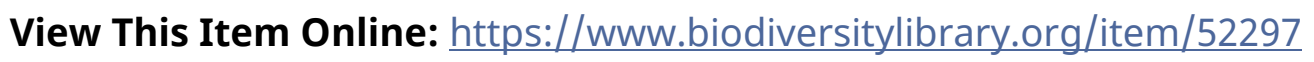

Permalink: https://www.biodiversitylibrary.org/partpdf/202820

\section{Holding Institution}

Smithsonian Libraries

\section{Sponsored by}

Smithsonian

\section{Copyright \& Reuse}

Copyright Status: Public domain. The BHL considers that this work is no longer under copyright protection.

This document was created from content at the Biodiversity Heritage Library, the world's largest open access digital library for biodiversity literature and archives. Visit BHL at https://www.biodiversitylibrary.org. 